\title{
A few last words on Far Eastern Dipterocarps
}

\author{
P.S. Ashton \\ The Arnold Arboretum of Harvard University, 125 Arborway, \\ Boston, MA 02130-3500, U.S.A. \\ and \\ Royal Botanic Gardens, Kew \\ Richmond, Surrey TW9 3AE, U.K. \\ pashton@oeb.harvard.edu
}

\begin{abstract}
Three additions to the Dipterocarpaceae are presented. Recent collections from southern Vietnam have finally revealed the identity of Dipterocarpus condorensis Pierre, necessitating reduction of $D$. caudatus Foxw. and nomenclatural adjustment of its subspecies; an unexpected novelty, Dipterocarpus pseudocornutus P.S.Ashton, is described from TawiTawi, SW Philippines; while a new lower montane point endemic, Vatica palongensis P.S. Ashton, is reported from West Kalimantan.
\end{abstract}

Keywords. Dipterocarpus, Kalimantan, Philippines, Vatica, Vietnam

\section{Introduction}

Although my 1982 Flora Malesiana account has held remarkably well, there has been a continuing trickle of novelties, as witnessed by the two new Shorea Roxb. ex Gaertn.f. species and one new Hopea Roxb. species in the Tree Flora of Sabah and Sarawak, that richest of dipterocarp provinces (Ashton, 2004); and new discoveries in the genus most easy to miss, Vatica L., from Peninsular Malaysia (Saw, 2002; Symington, 2004; Chua et al., submitted). The following further novelties have arisen while curating the Dipterocarpoideae held at the herbarium of the Royal Botanic Gardens, Kew. Notable has been the discovery of an isotype of Dipterocarpus condorensis Pierre, the Paris duplicate of which I have not had the opportunity to examine as it had been misplaced in the cabinets.

\section{Dipterocarpus condorensis resolved}

Dipterocarpus condorensis Pierre, Fl. For. Cochinch. 3, 14: P1.214 (1889); Smitinand, Vidal \& Hộ, Fl. Cambodge, Laos \& Viêtnam 25: 10 (1990). - TYPE: Vietnam, Pulau Condor, Pierre s.n. (lectotype K [K000671095], designated here).

Dipterocarpus condorensis subsp. condorensis

Dipterocarpus caudatus Foxw., Philipp. J. Sci., C 13: 177 (1918); Ashton, Gard. Bull. Singapore 31: 8 (1978); Ashton, Fl. Males., Ser. 1, Spermat. 9: 305 (1982); Ashton, 
Tree Fl. Sabah \& Sarawak 5: 94 (2004). - TYPE: Philippines, Luzon, Camarines Prov., Barrio Hibatac, Alvarez FB 21193 (lectotype K, designated by Ashton (1978)).

Dipterocarpus condorensis subsp. penangianus (Foxw.) P.S.Ashton \& Lưu, comb. nov. - Dipterocarpus penangianus Foxw., Malayan Forest Rec. 10: 72 (1932); Symington, Malayan Forest Rec. 16: 185 (1943); Ashton, Gard. Bull. Singapore 31: 8 (1963); Ashton, Man. Dipt. Brunei 43 (1964). - Dipterocarpus caudatus subsp. penangianus (Foxw.) P.S.Ashton, Gard. Bull. Singapore 31: 8 (1978); Ashton, Fl. Males., Ser. 1, Spermat. 9: 305 (1982); Ashton, PROSEA 5, 1: 174 (1993); Coode et al., Checkl. Fl. Pl. Gymnosperms Brunei Darussalam 68 (1996); Newman et al., Man. Males. Dipts., Philippines 66 (1996); Newman, Borneo Medium-Heavy Hardwoods 80 (1998); Ashton, Tree Fl. Sabah \& Sarawak 5: 97 (2004). - TYPE: Peninsular Malaysia, Penang, Mt. Olivia, Haniff SFN 3484 (holotype SING; isotype K).

Dipterocarpus caudatus auct. non Foxw.: Symington, Foresters' Man. Dipt. 364 (2004).

Additional specimens examined. VIETNAM: Bà Rịa-Vũng Tàu: Bình Châu-Phước Bửu Nature Reserve, branchlets with flowers and with young fruit, fallen ripe fruit, Luu Hồng Truờng 23, 24, 25 (K).

Notes. The identity of Dipterocarpus condorensis Pierre has remained a mystery for more than a century. It is based solely on fallen fruit, from the isolated Vietnamese island of Pulau Condor (Cộn Dấo) in the South China Sea, which do not closely match any Indo-Chinese species. I failed to find the presumed type, in the Paris herbarium, when preparing my account for Flora Malesiana (Ashton, 1982). Smitinand et al. (1990), in the Flore du Cambodge, du Laos et du Viêtnam, provided no description, merely quoting that of Pierre along with the number 5511 provided in Pierre's original description, implying that they also failed to find the type in Paris where two of the authors prepared the account. The Paris collection, furthermore, appears not to have been photographed. The entry under the name Dipterocarpus condorensis on the Paris herbarium website, barcode P05454280, consists only of notes on scraps of paper attached to a herbarium sheet, possibly in Pierre's hand, including a drawing of a dissected mature embryo which appears to be the draft of that in Pierre's plate. It is dated 1876, but unnumbered. There is a collection at Kew which, although not numbered by Pierre, bears the name and a description in Pierre's hand matching part of his protologue description. I formerly assumed it to represent abnormal fruit of the most similar Indo-Chinese species, Dipterocarpus turbinatus Gaertn.f., and named it accordingly. The fruit, however, differs from those of that species notably in its subspherical rather than ellipsoid-fusiform calyx tube, and shorter, to $6 \mathrm{~cm}$ versus to $13 \mathrm{~cm}$ long calyx lobes. The conundrum has now been resolved by Lưu Hồng Trường, who has collected material in flower, young and ripe fruit from Vũng Tàu on the southern Vietnamese coast, of a species not previously known from Indo-China. The fruit are an exact and diagnostic match for Dipterocarpus condorensis but the material 
as a whole matches the type subspecies of Dipterocarpus caudatus Foxw. from the Philippines. A further taxon is thus added to those which are confined to the Philippines and Indochina, including southernmost coastal China. Among dipterocarps, these include Dipterocarpus alatus Roxb. \& G.Don, and Vatica mangachapoi Blanco. In this case, though, there remains an overland link, Dipterocarpus condorensis subsp. penangianus, of coastal forests in Peninsular Malaysia and Northwest Borneo, which penetrates inland only in Ulu Temburong, Brunei, thus forming a link to those species which do occur in Indo-Burma, Peninsular Malaysia and the Philippines, but which are rare in northern Borneo except in the extreme west and north-east, notably Anisoptera costata Korth., Dipterocarpus hasseltii Blume and Shorea guiso (Blanco) Blume.

\section{New Malesian Dipterocarpaceae}

\section{Dipterocarpus pseudocornutus P.S.Ashton, sp. nov.}

Dipterocarpus cornutus superficie similis, alae calycis in fructu congeste contorto prominente differt. - TYPE: Philippines, Tawi-Tawi, Seratang Languyan, F.J.M. Gaerlan \& E.C. Sagcal PPI 10209 (holotype K).

Tree. Young parts densely shortly evenly buff pubescent, raceme and petiole persistently so; leaf blade beneath buff lanate. Bud not seen. Twig c. $5 \mathrm{~mm}$ diam. apically, stout, somewhat compressed. Leaf blade coriaceous, corrugate, ovate, 8-15(-21) $\times 4-8(-$ 11) $\mathrm{cm}$, apex subacute, base obtuse to narrowly subcordate; petiole $3-5 \mathrm{~cm}$ long, c. 3 $\mathrm{mm}$ diam. Raceme to $15 \mathrm{~cm}$ long, hardly branched. Flower bud to $2 \mathrm{~cm}$ long; calyx tube $12 \times 8 \mathrm{~mm}$, ellipsoid with intricately folded wings to $6 \mathrm{~mm}$ wide; stamens c. 30 , anthers $4 \mathrm{~mm}$ long at anthesis, lorate, with $4 \mathrm{~mm}$ filiform appendages. Fruit unknown.

Notes. This extraordinary collection, from islands populated by the Moro people and long thought deforested, was apparently found in a patch of degraded forest. Had it been without flowers, it would have likely been claimed as a major extension of the range of Dipterocarpus cornutus Dyer, a species of Peninsular Malaysia and the slightly seasonal northern Sumatra and south-eastern and southern Borneo. The densely intricately folded wings of the calyx either implies that this character is evolutionarily plastic, or that this new taxon is allied to others which bound the South China Sea: Dipterocarpus lamellatus Hook.f., of SW Sabah and Brunei, D. lowii Hook.f., which follows the expanded Riau Pocket excepting Simeulue (Ashton, 2014), and D. intricatus Dyer, of southernmost Indo-China.

Vatica palungensis P.S.Ashton, sp. nov.

Similar to Vatica oblongifolia Hook.f., especially to V. oblongifolia subsp. selakoensis P.S.Ashton, and to $V$. dulitensis Symington, but with terete twigs (vs compressed), a sparse buff indumentum (vs dense vinous), and 8-10 pairs of secondary veins (versus $\geq 10$ ). - TYPE: Indonesia, Kalimantan Barat, Ketapang, Gunung Palung National 
Park, Lower montane kerangas forest over granite, $665 \mathrm{~m}$, T.G. Laman, I.A. Rachman, \& E. Mirmanto TL 772 (holotype K; isotype A).

Young parts sparsely rugose grey-brown pubescent. Twig c. $2 \mathrm{~mm}$ diam. at first, terete. Leaf blade coriaceous, drying pale grey-brown above, ocherous beneath, narrowly elliptic-ovate to elliptic-obovate, $7-15 \times 3-6 \mathrm{~cm}$, acumen to $1 \mathrm{~cm}$ long, broad, base obtuse; veins $8-10$ pairs, ascending, raised on both surfaces, more so beneath; petiole 8-15 mm long, $1.5 \mathrm{~mm}$ diam., slender. Raceme short. Flowers unknown. Fruit to 10 $\mathrm{mm}$ diam., globose, rugulose; sepals to $3 \times 2.5 \mathrm{~mm}$, obtuse, becoming reflexed.

Additional specimens examined. INDONESIA: Kalimantan Barat: Ketapang, Gunung Palung National Park, Lower montane kerangas forest over granite, $705 \mathrm{~m}$, T.G. Laman, I.A. Rachman, \& E. Mirmanto TL 1374 (K, A), ibidem, $1000 \mathrm{~m}$, fallen leaves and fruit, P.S. Ashton s.n. (A).

Notes. Superficially a member of the endemic Borneo species group around the widespread Vatica oblongifolia Hook.f. which share a short powdery vinous indumentum. The present species differs from others notably in its tomentum. As in so many groups of sister dipterocarps, these species are particularly well represented in the north-west. At present a point endemic, this novelty also shares the narrow range and high habitat specificity of several of the others.

\section{References}

Ashton, P.S. (1982). Dipterocarpaceae. In: Van Steenis, C.G.G.J. (ed) Flora Malesiana, Series I, $9(2): 237-552$.

Ashton, P.S. (2004). Dipterocarpaceae. In: Soepadmo, E. \& Saw, L.G. (eds) Tree Flora of Sabah and Sarawak 5: 63-388, 485-496.

Ashton, P.S. (2014). On the Forests of Tropical Asia: Lest the Memory Fade. UK: Royal Botanic Gardens, Kew and USA: The Arnold Arboretum of Harvard University.

Chua, L.S., Nor-Ezzawanis, A.T, Yong, W.S.Y. \& Hamidah, M. (submitted). Two new species of Vatica from Peninsular Malaysia. Phytotaxa.

Saw, L.G. (2002). A new species of Vatica (Dipterocarpaceae) from Peninsular Malaysia. Gard. Bull. Singapore 54: 247-251.

Smitinand, T., Vidal, J.E. \& Hộ, P.H. (1990). Diptérocarpacées. In: Morat, Ph. (ed) Flore du Cambodge, du Laos et du Viêtnam, vol. 25. Paris: Muséum National d'Histoire Naturelle.

Symington, C.F. (2004). Foresters' Manual of Dipterocarps. Malayan Forest Records No. 16. Revised by Ashton, P.S. \& Appanah, S., edited by Barlow, H.S. Kepong: Forest Research Institute Malaysia and Kuala Lumpur: Malaysian Nature Society. 


\section{$2 \mathrm{BHL}$ Biodiversity Heritage Library}

Ashton, Peter S. 2015. "A few last words on Far Eastern Dipterocarps." The Gardens' bulletin, Singapore 67(2), 357-360.

https://doi.org/10.3850/s2382581215000290.

View This Item Online: https://www.biodiversitylibrary.org/item/223140

DOI: https://doi.org/10.3850/s2382581215000290

Permalink: https://www.biodiversitylibrary.org/partpdf/229527

\section{Holding Institution}

Singapore Botanic Gardens, National Parks Board Singapore

\section{Copyright \& Reuse}

Copyright Status: In copyright. Digitized with the permission of the rights holder.

License: http://creativecommons.org/licenses/by-nc-sa/4.0/

Rights: https://biodiversitylibrary.org/permissions

This document was created from content at the Biodiversity Heritage Library, the world's largest open access digital library for biodiversity literature and archives. Visit BHL at https://www.biodiversitylibrary.org. 